\title{
The Future of Knowledge in Theology
}

\author{
Marius Nechita
}

\begin{abstract}
The knowledge of God is often associated to seeing. The soul that sees God knows Him and recognizes Him. Seeing has a special importance as it assures you participation to the Seen one. But, in order to able to see you have to be in the same light as the Seen one, you have to be like Him. During Christ's Transfiguration on Tabor Mountain, the Apostles recognized Christ's glory of God "as much as they could" since they were also in the same divine light. The Lord was always covering Himself with light as a garment, but the disciples weren't "transfigured" after Christ's likeness, so they could have seen Him. Motovilov could also see the face of Saint Seraphim of Sarov because his face glowed from Holy Spirit's grace, too. The person who looks at another one inwardly receives some of his attributes.

KEY WORDS: future ,knowledge, Theology, virtual, faith, technology, communion.
\end{abstract}

$W_{\text {when Saint }}^{\text {e are almost twenty-one centuries away from the moment }}$ altar sacred "to the God of whom there is no knowledge" (Acts 17: 23). No doubt, this altar had been raised by the highest ambassadors of human cogitation, by the philosophers that have had reached the edges of knowledge. For natural human understanding, these edges are up to the present unsurpassed ${ }^{1}$ as there is no way to reach knowledge of God through a rational cogitation. Human nature, built up according to God's image withholds in it not only the possibility of knowing the Creator, but also the possibility of becoming alike Him. 
The border of not knowing God appears as a final success of Greek's classical wisdom. Up to the present, no philosopher or scientist has succeeded to get over this threshold if they remained faithful to the mind and to his natural cogitation or faithful to science and philosophy methods.

Saint John, the Apostle and Evangelist, debated over the existential character of knowledge, about knowledge assumed as life: And this is eternal life: to have knowledge of you, the only true God, and of him whom you have sent, even Jesus Christ (John 17:3). Besides Embodied Christ, no spiritual, philosophical or mystical experience provides man with the possibility of knowing God the way He IS, as Objectivity one who is unreached, absolute, in Three unreached absolute subjects. Man aspires to materialize in a creative manner his mental vision, to project the power of ideas and knowledge. No one else but the Holy Spirit, the Spirit of the Truth, guides us, actually carries us towards the knowledge of God's Son, teaches us to experience God as Love, as the Merciful, as Pantocrator, "trough crosses we didn't want" and through "resurrections that I wouldn't ask for" (Radu Gyr). In order to know God we need to follow him to the Cross, to the Hell and to the Resurrections. If speaking about God (theology) doesn't come with living, the knowledge you get is just a theoretical, scholastically, lifeless, infructuos one.

The knowledge of God is often associated to seeing. The soul that sees God knows Him and recognizes Him. Seeing has a special importance as it assures you participation to the Seen one. But, in order to able to see you have to be in the same light as the Seen one, you have to be like Him. During Christ's Transfiguration on Tabor Mountain, the Apostles recognized Christ's glory of God "as much as they could" since they were also in the same divine light. The Lord was always covering Himself with light as a garment, but the disciples weren't "transfigured" after Christ's likeness, so they could have seen Him. Motovilov could also see the face of Saint Seraphim of Sarov because his face glowed from Holy Spirit's grace, too. The person who looks at another one inwardly receives some of his attributes. There takes place a communication and by looking, you have communion with the seen One (Eucharist), and furthermore by Eucharist you remain in communion with Him; you 
become like Him (co-union), you co-live (syn-choresis) along with God. This co-living takes place in the space (chorus) that is Christ's Body-the Church. God is unknowable and incomprehensible in his essence, He is only knowable through His actions and grace. In "The life of Moses", Saint Gregory of Nyssa speaks about this seeing into unseeing, ${ }^{2}$ idea resumed later by theologians like Vladimir Loskky or father Dumitru Stăniloae. Christ's Transfiguration icon expresses best the paradoxical and tensioned relationship between knowledge and unknowing, between light and dark. In this icon, Christ is surrounded by an almond painted in dark colors, as an expression of light explosion and light abundance.

Adam had seen God's glory and remained alive, but disobeying the commandment he went blind and eventually died due to his lack of regret, says Simeon the New Theologian. The Soul is now like an eyeless body that sees God no more. ${ }^{3}$ Thus, humankind passes from the seeing sphere to the one of hearing God's voice that was preparing Adam, as a hole, so he will recognize the original Image "when the time had come" (Galatians 4:4). Hearing God's voice (coli Yahweh) that reveals His will in front of the chosen people, is in a close bond to obedience. The one who hears the commandment fulfills it, but those who don't hear it are also spiritually deaf. The redemptive Word comes through hearing and those who listen to it are troubled to their hearts towards fulfilling this word. Through hearing, man is receiving more general things, easier for knowledge, but only together with seeing there is being born the overwhelming person, the hypostasis and complete communion with the Seen one, in man.

In The Old Testament, dialog replaces contemplation. Israel's God is a hidden God (Isaiah 45:15) who declares Himself transcendent to any image that might make his nature know (Deuteronomy 4:15-16): "So keep watch on yourselves with care; for you saw no form of any sort on the day when the voice of the Lord came to you in Horeb out of the heart of the fire: So that you may not be turned to evil ways and make for yourselves an image in the form of any living thing, male or female." Even so, the heavens and earth Creator does not remain an unknown God. His reveals His name, He speaks and requires answer, He dialogues personally with humans: "And 
the voice of the Lord came to you out of the fire: the sound of his words came to your ears but you saw no form; there was nothing but a voice." (Deuteronomy 4:12)

In The Old Testament there are fragments with a formal negation for any potential seeing of the invisible, unknowable, inaccessible God to created beings and there are other fragments that recommend looking for God's face as the ultimate man's blessedness. On this line, "those who have clean hands and a true heart" (Psalms 24:4) are named "the generation of those whose hearts are turned to you, even to your face, 0 God of Jacob" (Psalms 24:6), for then, in "in the last days" those pure in heat shall be blessed for they shall see God (Matthew 5:8). Saint Gregory of Nyssa highlights that blessedness doesn't mean knowing something about God, but seeing Him in you. ${ }^{4}$

Moses had asked to see God's face (panîm) (Isaiah 33:12-13) because the Other one's face means a communion with that One and this strengthens Law's discovery as “a Word that isn't pronounced by a face is a delusive word, it bears within it the temptation suspicion and the lying spirit for there is no one to put testimony for him and to guarantee for him." ${ }^{5}$ Moses received a figurative seeing of God, he sees His backside on Sinai Mountain, but he couldn't see His face and still go on living (Exodus 33:20). Moses along with the entire humankind hadn't been prepared to see God, but they would have seen Him later in the last days (Galatians 4:4) on Tabor Mountain when He came as human, the Embodied Word. Moses had seen on Sinai resemblances of God's shine as a foresight of the future Tabor view. $^{6}$

We talk with God on earth like Moses "in cloud", because the Lord settled a dark between us and Him so we look even more to the light we found with great toil. Only if you look to God's things from exterior, you see Him as in dark, but the more a man deepens in God, he is deifying more and more, and He appears as light. Seeing God in dark ( $c f$. Isaiah 20:21) represents the moment of "God's knowing and reaching helplessness." Limited to biological life borders-the knowledge of God cannot reach to its complete achievement, but here in this existence begins the spiritual progress that is accomplished 
in God's Kingdom through the rest in God's Life and only after that "we will see Him as He is" (I John 3, 2-3).

In The New Testament the concept of dark, referring to seeing and knowing Lord, ${ }^{8}$ doesn't appear. God "is light and in him there is nothing dark" (I John 1:5); and this is because the genuine Light that lights every man (John1:9) comes in this world in order to deliver us from dark and passion. In the last days (Galatians 4:4), the Lord bowed towards earth and there found His image. Back then, the Gospel of knowing God was preached in this world: Holy Trinity one in essence, the mystery that many prophets had wanted to see and hear, but didn't (Luke 10:24).

At theology institutes, there are, for centuries, teachers trying out to present to their students, of a systematical manner, Church's dogma content about God. Thus, in a few years of theological education, there is the possibility of theoretical knowledge of many things about God, yet the school cannot offer a essential knowledge of God. Man can gain that kind of knowledge, with God's will, as a personal effort result: asceticism, prayer, virtues observation. When systematization reaches the limit, then the experience is replaced with an inert scholastic, becoming a philosophy and a scientific discipline. Without the prayer where man's soul meets the divine everlastingness in a essential manner and without this man's personal dialogue with God, the intellectual and theoretical knowledge may lead to a radical destruction of what God has given within the cloven tongues like as of fire. ${ }^{9}$ Holy Trinity's acknowledge is prayer's peak. This knowledge doesn't belong to rationality, as it is the case of the knowledge following sciences and human methods of research. Scientific and philosophical knowledge is a secular one that is bordered by this world's laws. Yet, the knowledge following spiritual prayer is a different knowledge, above this world, more profound, mystical, unspoken and personal. Prayer transfigures the one who is practicing it into a theologian, as Saint Nil the Ascetic (other think is Evagrius) states: If you are theologian, pray as you mean it; and if you are praying like you mean it, you are theologian.

The future of knowledge in Theology depends on gaining the Holy Spirit. It requires denial of passions, an inner cleanse in order to receive Holy Spirit's grace. Man can only constitute his 
being as a place of God, as a theophanic place of His presence, ${ }^{10}$ as "bed" (Song of Songs 3:1) meant for God so He can rest. Saint Gregory of Nyssa describes this bed as the soul-bride with the Groom-Christ communion: each loving person who is looking to find Christ becomes "bed" for Him where the beloved One rests. Love neutralizes the margin and makes the immensurable One feel comfortable within the one who, despite his limited essence (man), is able to comprise the immensurable One, in love.

Saint Simeon the New Theologian doesn't reject apriori any intellectual study in Theology, but opposes to it an intellectual contemplation accomplished by the Holy Spirit. Holy Spirit is the only principle for any Christian cognition. The Truth's Spirit illuminates man, teaches him how to understand God being unspoken. Without this illumination, God cannot be known and the Spirit rests no longer into a soul controlled by passions. Saint Clement of Alexandria states the impossibility for the man with bodily pleasures to be like Lord or to gain His cognition. ${ }^{11}$ Not knowing God is shown by the man's way of living, whilst the man knowing his Creator has a different way of living, well-pleasing to Him.

In the meeting between Nicodemus and Jesus episode, Saint John's Gospel offers the best proof of culture and intellect impossibility to constitute paths towards God, by themselves, but we are offered with a testimony that Christ has come not only for publicans and harlots, but for scribes, for wise and eager for knowledge ones. Intellectual knowledge can sustain faith and God's re-cognition. For the early times of a century predominated over information, technology and IT, Nicodemus is the mad hope of intellectuals. $^{12}$

Christianity has urged intellect's margins, as he doesn't propose prescriptions but offers and indicates directions. Nowadays people feel comfortable being knowledgeable well-informed beings, but Christians, those truly alive people, are those who re-cognize God during this life. Holy Spirit, settled within man since holy Baptism, is teaching him they way to be a (re)cognizing and Eucharistic (grateful and sacrificial) being.

Our path towards God's knowledge goes not only through books, but especially through our belief in Christ's word and our 
prayer that became a living dialogue with God. When Holy Spirit increases the knowledge within us and broadens our conscience, then the prayer gains cosmic dimensions, as it embraces the whole world as we ask all humans the grace with the same heart, as for us.

As observed in its millenary experience, the Orthodox Church knows that God who is above any understanding, name or image in His essence. Through an experience limited to human powers, holy fathers partook to this knowledge that they have left us as a precious legacy which shall not be taken away from us (cf. Luke 10:42). As regarding to His love and benevolence for man, God doesn't despise our nothingness, but provides us with the possibility of knowing Him through prayer's dialogue. God has assumed our human essence so man could eventually become god, in grace, as far as He had become man. In other words, the divine cognition has become human knowledge with the purpose of becoming once again divine cogitation. This is the direction of knowledge anchored in ontological structures: through Christ, in Holy Spirit.

NOTES:

${ }^{1}$ Archimandrite Sophrony Sakharov, Birth into the immovable Kingdom (Alba Iulia: Reîntregirea Publishing house, 2002), 41.

${ }^{2}$ Saint Gregory of Nyssa, Homilies, PSB Collection, no. 29 (Bucharest: The Biblical and Missionary Institute of the Romanian Orthodox Church, 1982).

${ }^{3}$ Saint Symeon the New Theologian, Hymns, Epistles and Chapters (Sibiu: Writings III, Deisis Publishing house, 2001), 276-277.

${ }^{4}$ Vladimir Lossky, The Vision of God (Sibiu: Deisis Publishing house, 1995), 74.

${ }^{5}$ Vianu Mureșan, Symbol. Icon. Image - a phenomenological sketch. (Cluj Napoca: Eikon Publishing house, 2006), 150.

${ }^{6}$ Vladimir Lossky, The Vision of God (Sibiu: Deisis Publishing house, 1995), 31.

${ }^{7}$ Archimandrite Sophrony Sakharov, God's ascetic knowledge (Alba Iulia: Reîntregire Publishing house, 2005), 193.

${ }^{8}$ Ioan-Gheorghe Rotaru, "The notion of Logos in the vision of John the Evangelist", in Proceedings in Human and Social Sciences at the Common Conference. The 2nd Human And Social Sciences at the Common Conference. (Zilina: 
EDIS-Publishing Institution of the University of Zilina, Thomson Ltd, Slovakia, 2014), 231-235.

${ }^{9}$ Idem, We shall see Him as He is: (Bucharest: Sofia Publishing house, 2005), 70 .

${ }^{10}$ Karl Christian Felmy, Dogmatic ecclesiastical experience. The renewal of contemporary Orthodox theology (Sibiu: Deisis Publishing house, 1999), 250.

${ }^{11}$ Saint Clement of Alexandria, The Stromata, III, 44.1-5, PSB Collection, no. 5 (Bucharest: The Biblical and Missionary Institute of the Romanian Orthodox Church, 1982), 206.

12 Nicolae Steinhardt, Through Giving You Shall Receive, Diocese of Maramureş and Sătmar Publishing house, Baia Mare, 1992, 13.

\section{BIBLIOGRAPHY:}

The Bible or The Holy Scripture. Bucharest: The Biblical and Missionary Institute of the Romanian Orthodox Church, 1988.

Idem, a revision version after the Septuaginta, redacted and annotated by the blessed Archbishop of Cluj Bartolomeu Valeriu Anania. Bucharest: The Biblical and Missionary Institute of the Romanian Orthodox Church, 2001.

Alexandria, Saint Clement of, The Stromata, III, 44.1-5, PSB Collection, no. 5. Bucharest: The Biblical and Missionary Institute of the Romanian Orthodox Church, 1982.

Felmy, Karl Christian, Dogmatic ecclesiastical experience. The renewal of contemporary Orthodox theology, Sibiu: Deisis Publishing house, 1999.

Krivoshein, Archbishop Basil, In the Light of Christ. Saint Simeon the New Theologian life and spiritual teaching. Bucharest: The Biblical and Missionary Institute of the Romanian Orthodox Church, 2005.

Lossky, Vladimir, The Vision of God. Sibiu: Deisis Publishing house, 1995.

Lossky, Vladimir, Idem, In the Image and Likeness of God. Bucharest: Humanitas Publishing house, 2006.

Mureşan, Vianu, Symbol. Icon. Image - a phenomenological sketch. Cluj Napoca: Eikon Publishing house, 2006.

Nyssa, Saint Gregory of, Homilies, PSB Collection, no. 29. Bucharest: The Biblical and Missionary Institute of the Romanian Orthodox Church, 1982.

Rotaru, Ioan-Gheorghe, "The notion of Logos in the vision of John the Evangelist", in Proceedings in Human and Social Sciences at the Common Conference. The 2nd Human And Social Sciences at the Common Conference. Zilina: EDIS-Publishing Institution of the University of Zilina, Thomson Ltd, Slovakia, 2014, 231-235.

Sakharov, Archimandrite Sophrony, God's ascetic knowledge, Reîntregire Publishing house, Alba Iulia, 2005.

Sakharov, Archimandrite Sophrony, Idem, Birth into the immovable Kingdom. Alba Iulia: Reîntregirea Publishing house, 2002. 
Sakharov, Archimandrite Sophrony, Idem, We shall see Him as He is. Bucharest: Sofia Publishing house, 2005.

Symeon the New Theologian, Hymns, Epistles and Chapters. Sibiu: Writings III, Deisis Publishing house, 2001. 